\title{
PERANCANGAN PENUTUP JEMURAN OTOMATIS MULTIFUNGSI MENGGUNAKAN METODE QFD (Quality Fungsional Deployment)
}

\author{
Rendra Soekarta ${ }^{1)}$ Irman Amri $^{2)}$ Suharsono ${ }^{3)}$, \\ 1). Dosen Pengajar Program Studi Teknik Informatika Universitas Muhammadiyah Sorong \\ 2). Dosen Pengajar Program Studi Teknik Industri Universitas Muhammadiyah Sorong \\ 3). Mahasiswa S-1 Program Studi Teknik Industri Universitas Muhammadiyah Sorong
}

\begin{abstract}
ABSTRAK
Kemajuan ilmu pengetahuan dan teknologi yang semakin pesat telah mendorong manusia untuk mengatasi segala permasalahan yang timbul di kehidupan. Hampir semua orang tidak bisa lepas dari dunia teknologi, baik itu teknologi sederhana maupun teknologi tinggi. contonya adalah alat-alat elektronik yang beragam dan mempermudah pekerjaan sehari-hari.

Dalam kehidupan sehari-hari menjemur adalah salah satu aktifitas yang terkadang sering kita lakukan bukan hanya menjemur pakaian, kasur dll aktifitas menjemur juga sering di lakukan oleh pelaku indutri perumahan contohnya indutri kerupuk, ikan asin, dan sebagainya. Akan tetapi salah satu kendala yang sering terjadi pada saat proses menjemur adalah datangnya hujan yang tiba-tiba, cuaca yang tidak menentu akan menghambat dan menghawatirkan aktifitas menjemur kita pada saat kita tinggal bepergian keluar rumah.

Dalam penulisan ini diamati apa yang diperlukan dalam hal mengatasi persoalan menjemur dihubungkan dengan semua aktifitas dan perubahan lingkungan yang terjadi yang berkaitan dengan penjemuran tersebut. Lalu ditentukanlah model dan desain yang dinginkan untuk mengatasi persoalan yang ingin diatasi, selanjutnya diperoleh rancangan jemuran sebagaimana diinginkan.
\end{abstract}

Kata kunci : Perancangan, Jemur, Otomatis, multifungsi Metode QFD

\section{PENDAHULUAN}

\section{Latar Belakang Penelitian}

Kemajuan ilmu pengetahuan dan teknologi yang semakin pesat telah mendorong manusia untuk mengatasi segala permasalahan yang timbul di kehidupan. Hampir semua orang tidak bisa lepas dari dunia teknologi, baik itu teknologi sederhana maupun teknologi tinggi. contonya adalah alat-alat elektronik yang beragam dan mempermudah pekerjaan sehari-hari.

Dalam kehidupan sehari-hari menjemur adalah salah satu aktifitas yang terkadang sering kita lakukan bukan hanya menjemur pakaian, kasur dll aktifitas menjemur juga sering di lakukan oleh pelaku indutri perumahan contohnya indutri kerupuk, ikan asin, dansebagainya. Akan tetapi salah satu kendala yang sering terjadi pada saat proses menjemur adalah datangnya hujan yang tiba-tiba, cuaca yang tidak menentu akan menghambat dan menghawatirkan aktifitas menjemur kita pada saat kita tinggal bepergian keluar rumah. Karna itulah perlu adanya sebuah inovasi produk yang dapat membantu meringankan aktifitas menjemur. Sebuah penutup jemuran otomatis yang dapatmembantu pada saat turun hujan tibatiba multi fungsi ergonomi. Perancangan produk ini menggunakan metode QFD (Quality Fungsional Deployment)

\section{Rumusan Masalah}

Berdasarkan uraian latar belakang di atas maka masalah yang akan di rumuskan adalah sebagai berikut:

1. Apa saja yang perlukan diperhatikan dalam pengambilan data Quisioner sebelum diterapkan pada metode QFD 
2. Apa saja yang perlu di perhatikan dalam pelaksanaan Metode QFD dalam perancangan sebuah produk penutup jemuran otomatis multi fungsi.

\section{Batasan Masalah}

Mengingat keterbatasan yang di miliki penulis dan serta kecakupan masalah yang terlalu luas maka penulis perlu untuk membatasinya. Adapun batasan masalahnya adalah sebagai berikut:

1. perancangan penutup jemuran otomatis di lakukan dengan metode QFD

2. permahasan hanya focus pada metode QFD dan atributnya dalam perancangan sebuah produk.

3. Tidak membahas biaya produksi produk penutup jemuran otomatis multi fungsi

\section{Tujuan Penelitian}

1. Menghasilkan produk yang dapat membantu dalam aktifitas sehari-hari kususnya menjemur.

2. Merancang penutup jemuran otomatis Multi fungsi berdasarkan kebutuhan pelanggan menggunakan metode QFD.

Tujuan dilakukannya penelitian ini antara lain :

1. Untuk mengetahui tingkat pelayanan di Sabili Motor terhadap kepuasan pada pelanggan.

2. Memudahkan karyawan untuk memberikan informasi data spare part kepada pelangan.

3. Mencegah hilangnya catatan baik data persediaan spare part atau yang lainya.

\section{METODOLOGI PENELITIAN}

\section{Tempat dan Waktu Penelitian}

Waktu penelitian dilakukan mulai tanggal 9 januari sampai tanggal 21 januari Penelitian dilakukan secara langsung dengan memberikan kuesioner yang berisi pertanyaan-pertanyaan seputar produk penutup jemuran kepada ibu-ibu rumah tangga dan remaja yang dirasa mampu menjadi responden, Pelaksanaan tempat penelitian adalah mengambil sampel secara acak yaitu ibu-ibu rumah tangga dan remaja yang dianggap masuk dalam kriteria pelaku aktifitas menjemur di kota dan kabupaten sorong.

\section{Tahapan Penelitian}

1. Tahapan Identifikasi Awal

2. Populasi dan sampel

3. Tahapan pengumpulan data

4. Tahapan Pengolahan Data

Data yang diperoleh kemudian diolah untuk mendapatkan perhitunganperhitungan di bawah ini:

1. Uji Validitas Data

2. Uji Relibilitas Data

\section{Penerapan Metode $Q F D$}

Dalam tahap ini quisioner sebagai alat bantu pengumpulan suara konsumen dalam perancangan produk penutup jemuran menggunakan metode $Q F D$

\section{PENGUMPULAN PENGOLAHAN DATA}

DAN

\section{Pengumpulan Data \\ Custemer Voice}

Pengumpulan data Custemer Voice dilakukan dengan memberikan Kuesioner kepada ibu-ibu rumah tangga dan para wanita remaja yang masuk kedalam kriteria responden, sebagai sumber pengambilan data, dan berikut ini adalah pertanyanpertanyaan dari kuesioner:

1. apakah anda seorang yang sering melakukan aktifitas menjemur?

2. Pada saat melaksanakan aktifitas menjemur, apakah anda merasa repot dengan keadaan cuaca yang berubahubah?

3. apakah anda memerlukan sebuah produk berupa produk jemuran yang bekerja secara otomatis, yang bekerja tertutup bila terjadi hujan dan terbuka kembali ketika hujan berhenti? 
Tabel 4.1. Costumer Need.

\begin{tabular}{|l|l|}
\hline No & Suara Konsumen (Custemer needs) \\
\hline 1. & Bahan ringan \\
\hline 2. & Mudah pemakaian \\
\hline 3. & Tidak mengangu saat penggunaan \\
\hline 4. & Murah \\
\hline 5. & Bekerja secara otomatis \\
\hline 6. & Bentuk yang simple \\
\hline 7. & Mudah disimpan \\
\hline 8. & Tahan lama \\
\hline 9. & Tidak berbahaya \\
\hline 10. & Kuat saat di pasang \\
\hline 11. & Dapat digunakan sebagai penutup jemuran multi fungsi \\
\hline 12. & Ukuran jemuran bisa disesuaikan sesuai keinginan \\
\hline 13. & Bisa ditempatkan dimana saja dengan media tembok \\
\hline 14. & Penutup jemuran terbuat dari bahan yang aman \\
\hline 15. & Mudah pemasangan \\
\hline 16. & Mudah perawatan \\
\hline 17. & Dapat di Nonaktikan saat tidak diperlukan \\
\hline 18. & Bisa dioprasikan kapan saja \\
\hline 19. & Tidak mengandung bahan berbahaya \\
\hline 20. & Memudahkan saat melakukan akttifitas menjemur \\
\hline
\end{tabular}

\section{Pengujian Instrumen}

\section{Uji Validitas Data}

Pengujian Instrumen dimaksudkan untuk mengetahui validitas dan rehabilitas sehingga dapat digunakan dalam proses analisa data untuk memperoleh data penelitian sesuai dengan fakta keinginan akan produk penutup jemuran.

\section{Uji Validitas}

Uji validitas digunakan sebagai pengujian sah atau tidaknya suatu kuesioner. (Ghozali,2005:45) Suatu kuesioner dikatakan sah/baik jika pertanyaan pada kuesioner mampu mengukapkan suatu yang akan diukur oleh kuesioner tersebut. Uji signifikasi dilakukan dengan cara membandingkan nilai $\mathrm{R}$ hitung dengan $\mathrm{R}$ tabel untuk degree of freedom $(\mathrm{df})=\mathrm{n}-2$, untuk menguji apakah masing-masing indicator valid atau tidak, dapat dilihat dalam tampilan output Cronbach Alpa pada kolom Corelation Item-Total Correlation. Jika $\mathrm{R}$ hitunglebih besar dari $\mathrm{R}$ tabel dan nilai positif maka bulir atau pertanyaan atau indicator tersebut dinyatakan valid. Uji validitas dilakukan dengan membanding kan nilai $\mathrm{R}$ hitung dan nilai $\mathrm{R}$ tabel (SPSS memberikan fasilitas untuk mengukur) 
Tabel 4.2 Hasil Pengujian Validitas

\begin{tabular}{|l|l|l|l|l|}
\hline No & Indikator & R-hitung & R-tabel & Keterangan \\
\hline 1 & Pertanyaan 1 & 0,410 & 0.279 & Valid \\
\hline 2 & Pertanyaan 2 & 0,458 & 0,279 & Valid \\
\hline 3 & Pertanyaan 3 & 0,438 & 0,279 & Valid \\
\hline 4 & Pertanyaan 4 & 0,467 & 0,279 & Valid \\
\hline 5 & Pertanyaan 5 & 0,625 & 0,279 & Valid \\
\hline 6 & Pertanyaan 6 & 0,459 & 0,279 & Valid \\
\hline 7 & Pertanyaan 7 & 0,418 & 0,279 & Valid \\
\hline 8 & Pertanyaan 8 & 0,441 & 0,279 & Valid \\
\hline 9 & Pertanyaan 9 & 0,427 & 0,279 & Valid \\
\hline 10 & Pertanyaan 10 & 0,579 & 0,279 & Valid \\
\hline 11 & Pertanyaan 11 & 0,712 & 0,279 & Valid \\
\hline 12 & Pertanyaan 12 & 0,375 & 0,279 & Valid \\
\hline 13 & Pertanyaan 13 & 0,650 & 0,279 & Valid \\
\hline 14 & Pertanyaan 14 & 0,582 & 0,279 & Valid \\
\hline 15 & Pertanyaan 15 & 0,525 & 0,279 & Valid \\
\hline 16 & Pertanyaan 16 & 0,432 & 0,279 & Valid \\
\hline 17 & Pertanyaan 17 & 0,569 & 0,279 & Valid \\
\hline 18 & Pertanyaan 18 & 0,533 & 0,279 & Valid \\
\hline 19 & Pertanyaa 19 & 0,262 & 0,279 & Tidak Valid \\
\hline 20 & Pertanyaan 20 & 0,521 & 0,279 & Valid \\
\hline
\end{tabular}

\section{Uji Reliabilitas}

Ghozali (2006:41) Uji Reliabilitas adalah alat untuk mengukur suatu kuesioner yang merupakan indicator-indicator,

\section{Tabel 4.3 Hasil Uji Relibilitas}

\begin{tabular}{|l|l|l|l|}
\hline No & Variabel & Alpha & Keterangan \\
\hline 1 & Pertanyaan 1 & 0,839 & Reliabel \\
\hline 2 & Pertanyaan 2 & 0,710 & Reliabel \\
\hline 3 & Pertanyaan 3 & 0,853 & Reliabel \\
\hline 4 & Pertanyaan 4 & 0,895 & Reliabel \\
\hline 5 & Pertanyaan 5 & 0,857 & Reliabel \\
\hline 6 & Pertanyaan 6 & 0,803 & Reliabel \\
\hline 7 & Pertanyaan 7 & 0,728 & Reliabel \\
\hline 8 & Pertanyaan 8 & 0,707 & Reliabel \\
\hline 9 & Pertanyaan 9 & 0,799 & Reliabel \\
\hline 10 & Pertanyaan 10 & 0,755 & Reliabel \\
\hline 11 & Pertanyaan 11 & 1,001 & Reliabel \\
\hline 12 & Pertanyaan 12 & 0,904 & Reliabel \\
\hline 13 & Pertanyaan 13 & 0,981 & Reliabel \\
\hline 14 & Pertanyaan 14 & 0,795 & Reliabel \\
\hline 15 & Pertanyaan 15 & 0,833 & Reliabel \\
\hline 16 & Pertanyaan 16 & 0,699 & Reliabel \\
\hline 17 & Pertanyaan 17 & 0,960 & Reliabel \\
\hline 18 & Pertanyaan 18 & 0,795 & Reliabel \\
\hline 19 & Pertanyaan 20 & 0,790 & Reliabel \\
\hline
\end{tabular}

variabel atau kontruk. Suatu kuesioner dikatakan Reliable atau handal jika jawaban seseorang terhadap pertanyaan adalah stabil dari waktu ke waktu. 
Tabel4.9 hasil house of quality

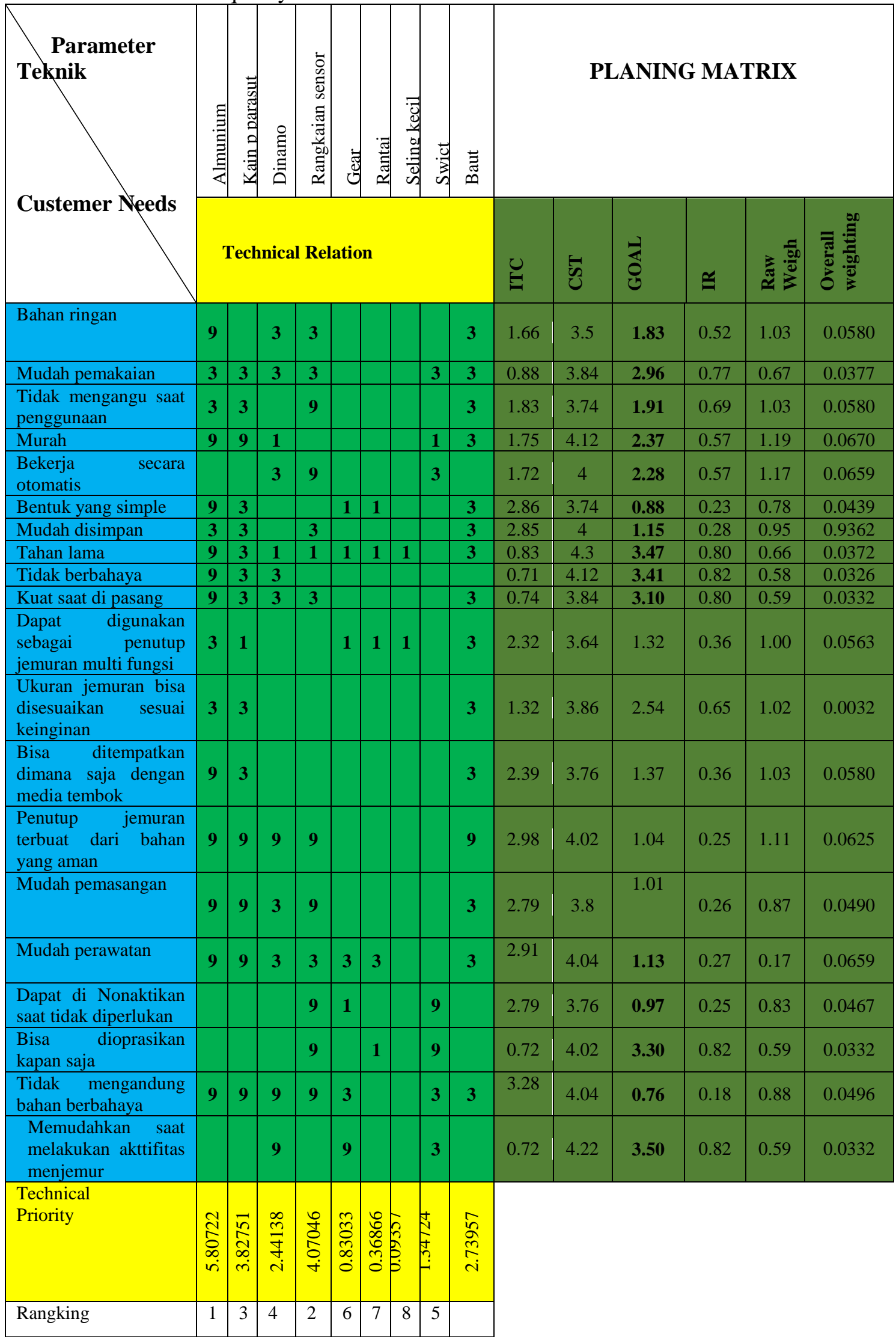




\subsection{Perancangan Produk}

Setelah melakukan pengolahan data penelitian dan setelah melakukan perancangan produk penutup jemuran otomatis multi fungsi menggunakan metode QFD, kemudian hasilnya akan

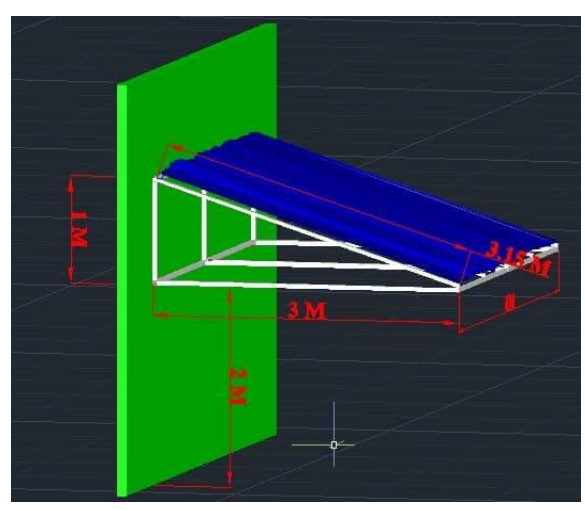

diimplementasikan ke sebuah gambar menggunakan software autocad sebelum perancangan produk ini benar-benar akan di buat. Gambar tesebut dapat dilihat dibawah ini:

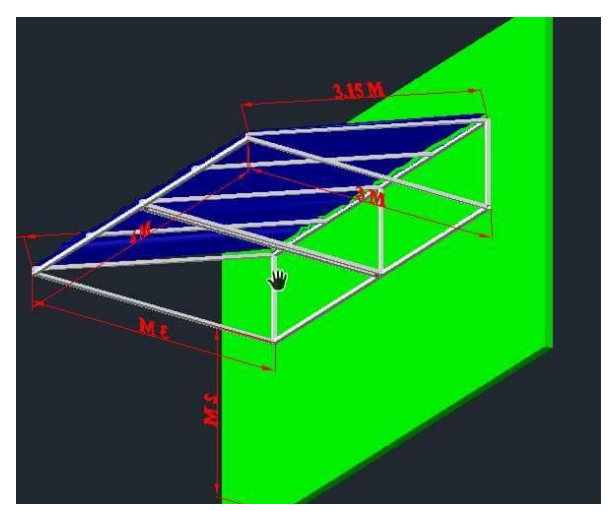

\section{KESIMPULAN DAN SARAN}

\section{Kesimpulan dan saran}

Kesimpulan dari hasil penelitian yang penulis lakukan dalam perancangan produk penutup jemuran otomatis menggunggunakan metode QFD (Quality Fungctional Deployment) adalah tahapan pengambilan data pengolah data hingga penentuan priority dangan didapat sebuah disain perancangan yang sesuai dengan keinginan konsumen yaitu penutup jemuran automatis

\section{Saran}

Dalam peneltian ini penulis masih banyak kekurangan dalam pengimplementasian metode QFD (quality functional Deployment) diharapkan jika ada yang 


\section{DAFTAR PUSTAKA}

Pribadi, Rian permana (2013) Program studi teknik Industri. (TA No.05.07008.2013). Deasain Produk Holder Connector VGA Dengan Quality Function Deployment (QFD), Universitas Widyatama.

Pribadi, Adhitya Wahyu Wicaksono (2013) Program Studi Teknik Elektro. (TA No.09501244027.2013). Penerapan Metode QFD (Quality Function Deployment) Padarencana Pengembangan Sekolah Di SMKN 2 Yogyakarta. Universitas Negeri Yogyakarta.
Pristianto, H., Amri, I., \& Rusdi, A. (2018). Pedoman Penulisan Tugas Akhir Fakultas Teknik Universitas Muhammadiyah Sorong.

Wikipedia ensiklopedia bebas.(2009). Blogspot. Retrived Februari 15, 2016, from http://eje.blogspot.co.id/2009/02/quqlityfunction-deployment-qfd.html?m=1

Wikipedia ensiklopedia bebas.(2013).googlewebligt.

Retrived Agustus 22, 2013, from http://googleweblight.com/?lite_url= $\underline{\text { http://datariset.com/ol }}$ 